\title{
Feeding deterrency in Antarctic marine organisms: bioassays with the omnivore amphipod Cheirimedon femoratus
}

\author{
Laura Núñez-Pons ${ }^{1, *}$, Mariano Rodríguez-Arias ${ }^{2}$, Amelia Gómez-Garreta ${ }^{3}$, \\ Antonia Ribera-Siguán ${ }^{3}$, Conxita Avila ${ }^{1}$
}

${ }^{1}$ Departament de Biologia Animal (Invertebrats), Facultat de Biologia, Universitat de Barcelona, Av. Diagonal 643, 08028 Barcelona, Catalunya, Spain

${ }^{2}$ Departamento de Matemáticas, Facultad de Ciencias, Universidad de Extremadura, Avda. de Elvas S/n, Badajoz 06006, Spain

${ }^{3}$ Departament de Productes Naturals, Biologia Vegetal i Edafologia (Botànica), Facultat de Farmàcia, Universitat de Barcelona, Joan XXIII, s/n, 08028 Barcelona, Catalunya, Spain

\begin{abstract}
The main predators of Antarctic benthic organisms are vagile invertebrates, including dense amphipod populations. Marked seasonalities of food availability drive consumers to develop opportunistic behaviors, which favors the evolution of defensive chemistry in potential prey. We used the circumpolar omnivorous amphipod Cheirimedon femoratus and a new feeding preference assay using alginate caviar-textured food pearls to examine the incidence of lipophilic deterrents in Antarctic benthic organisms. The method showed remarkable discriminatory potential for unpalatable metabolites. We obtained a total of 52 fractions from 40 samples that represented 31 species (including sponges, cnidarians, ascidians, a bryozoan, an echinoderm, a hemichordate and algae) from the Weddell Sea and the South Shetland Islands. Unpalatability was found in 42 extracts from 26 species. The remaining 10 extracts from 7 samples did not exhibit unpalatability, indicating either that deterrents are contained in fractions not tested here, or that alternative defensive traits might protect these organisms. Within the 4 major taxonomical groups, the ascidians showed the highest repellencies, followed by sponges, cnidarians, and algae. These organisms from distant Antarctic locations may represent both host biosubstrata and potential prey for C. femoratus. Thus, this amphipod could be a significant inducer of chemical protection in its hosts due to the localized and constant contact created by inhabiting and feeding on the same organism. Defense sequestration in specific body-structures, as predicted by the Optimal Defense Theory, was detected in an octocoral sample. We suggest that some of the tested organisms could combine several defensive strategies to prevent predation. Altogether, our results indicate that chemical defenses are broadly used among Antarctic benthic organisms to avoid predation by the opportunistic amphipod C. femoratus, and thus, chemical ecology is a key aspect in the functioning of Antarctic ecosystems.
\end{abstract}

KEY WORDS: Cheirimedon femoratus - Antarctic invertebrates · Antarctic algae $\cdot$ Chemical ecology $\cdot$ Omnivorous amphipod $\cdot$ Unpalatability $\cdot$ Feeding preference assays

Resale or republication not permitted without written consent of the publisher

\section{INTRODUCTION}

Antarctic marine ecosystems are characterized by low temperatures and pronounced seasonality, with periodic limitations of food resources. Despite some shallow coastal regions (less than approx. $30 \mathrm{~m}$ depth) exposed to ice scour and anchor ice, the benthic habitat appears to be physically stable and 'biologically accommodated' (Gutt 2000). Hence, species distribution and abundance in these communities are 
considered to be largely regulated by predatory and competitive interactions (Dayton et al. 1974). The continental shelf of Antarctica houses a rich suspension-feeding macroinvertebrate assemblage comprised of mainly sponges, soft corals, bryozoans, hydroids, and ascidians, as well as abundant macroalgae in the photic zone (Gutt et al. 2000, Wiencke et al. 2007). Higher trophic levels include mostly high densities of opportunistic crustacean amphipods (De Broyer \& Jazdzewski 1996, Huang et al. 2007), as well as generalist macroinvertebrate predators like nemerteans and asteroid echinoderms, and fish (Richardson 1975, Dearborn 1977, Gutt et al. 2000, Obermuller et al. 2010). These keystone predators, especially sea stars and amphipods, cause intense predation pressure, and are commonly circumpolar in distribution. Thus, sessile and slow-moving organisms from distant Antarctic regions are affected by the foraging activities of these ubiquitous predators (Dayton et al. 1974, De Broyer et al. 2007). The Antarctic biota is very ancient (originating at least 22 million yr ago) and endemic (Gutt 2000). These facts suggest that interactions between species provided many opportunities for the evolution of defensive mechanisms. One common tactic is chemical defense, characterized by the biosynthesis or storage of dietary products with toxic, noxious or unpalatable properties (Paul 1992). Presumably, the organisms must balance the energetic costs of defense against those of growth and reproduction. According to the Optimality Theory (OT), common defensive traits should be effective against a variety of enemies in order to save energy and mostly addressed towards generalists (Herms \& Mattson 1992, Sotka et al. 2009). Moreover, the Optimal Defense Theory (ODT) predicts that chemical defenses should be sequestered in those tissues that are most vulnerable (in terms of fitness) and frequently targeted by predators, and in co-ordination with other defensive mechanisms (Rhoades \& Gates 1976). Thus, defenses should be concentrated in the outermost zones, where they would be most effective against a number of predators that first encounter the prey's surface. But in perforated prey (e.g. sponges), in which small grazers may access inner tissues, defenses should also be found in the internal parts.

In Antarctic benthic communities, peracarid crustaceans, and especially Amphipoda, are by far the most species-rich group and probably the most diversified with respect to lifestyles, trophic types (including necrophagy, carnivory, herbivory, suspension feeding, detritivory, and omnivory), habitats and size spectra (De Broyer \& Jazdzewski 1996). They com- monly associate temporarily with living substrata (frequently macroalgae and sponges but also others), which are often also their potential (direct or incidental) prey (De Broyer et al. 2001). In tropical areas, these small crustaceans are effective inducers of chemical defense in their associated host and potential prey, because of the intense localized pressure they exert on these species (Cronin \& Hay 1996, Toth et al. 2007). Amphipods appear in very high densities off the Western Antarctic Peninsula (up to 300000 individuals $\mathrm{m}^{-2}$; Huang et al. 2007), higher than in other latitudes (Nelson 1980). Antarctic amphipods strongly influence the population dynamics of benthic biota, since they feed on a wide array of taxa, including macroalgae, sponges, cnidarians, holothurians, bryozoans, and diatoms (Coleman 1989a,b, 1990, Graeve et al. 2001, Nyssen et al. 2005, Huang et al. 2006, 2007, Amsler et al. 2009, McClintock et al. 2009), and are relevant in terms of energy flux in the shelf ecosystem, because they are an important food source for demersal fishes (Richardson 1975).

Feeding deterrents are widespread in Antarctic communities, but the effect of generalist amphipods on the prevalence of these protective metabolites in their prey species has received scarce attention (for reviews see Avila et al. 2008, McClintock et al. 2010), even though these consumers are considered important inducers of defensive chemistry (Cronin \& Hay 1996, Toth et al. 2007). The lysianassid amphipod Cheirimedon femoratus, with a circumpolar distribution and eurybathic occurrence down to $1500 \mathrm{~m}$ depth (De Broyer et al. 2007, Krapp et al. 2008), is described as a voracious, omnivorous, opportunistic scavenger, except for ovigerous females and newly hatched young, which ingest mostly photosynthetic material (algae) during summer (Bregazzi 1972b). In fact, it is a first-arrival feeder at carrion inputs (Smale et al. 2007). As a very abundant generalist feeder (animal, micro- and macroalgal material and detritus) (Bregazzi 1972b), C. femoratus is likely a consumer towards which most potential prey inhabiting the Antarctic shelf would address defensive chemistry. C. femoratus has reduced swimming abilities and loose host relationships (Bregazzi 1972b, authors' pers. obs.). The present study is the first to use this ubiquitous amphipod as model predator to perform palatability bioassays, with samples coming from variable depths of the scarcely studied Weddell Sea and the South Shetland Archipelago. Since most known marine repellents are lipid-soluble (Sotka et al. 2009), lipophilic extracts from Antarctic benthic invertebrates and algae were selected for experimentation. The aim of this study was to evaluate the 
presence of chemical defenses (in the form of unpalatable substances) in Antarctic benthic organisms and to determine the within-body allocation of defenses when possible. Furthermore, a new protocol for feeding preference assays is proposed.

\section{MATERIALS AND METHODS}

\section{Selection and sampling of model predator}

In our search for an appropriate experimental consumer, we assessed 3 of the most abundant species around the Antarctic Spanish Base (BAE) 'Gabriel de Castilla' on Deception Island (62 $59.369^{\prime} \mathrm{S}$, $60^{\circ} 33.424^{\prime} \mathrm{W}$ ). Selective trials were performed with the limpet Nacella concinna, the sea urchin Sterechinus neumayeri, and the amphipod Cheirimedon femoratus. The predator needed to be ubiquitous and omnivorous, because extracts from various animals and algae coming from distant locations were being evaluated. Since the limpet and the urchin consistently consumed very little under laboratory conditions - in agreement with previous reports (e.g. Amsler et al. 2005b) — and were not strictly omnivorous, we chose the amphipod as model predator.

Hundreds of individuals of the amphipod Cheirimedon femoratus were captured along the shoreline of the Spanish Antarctic Base between 2 to $7 \mathrm{~m}$ depth during the Antarctic cruise ACTIQUIM-2 in January 2010 (Fig. 1) for feeding experiments. Collection was

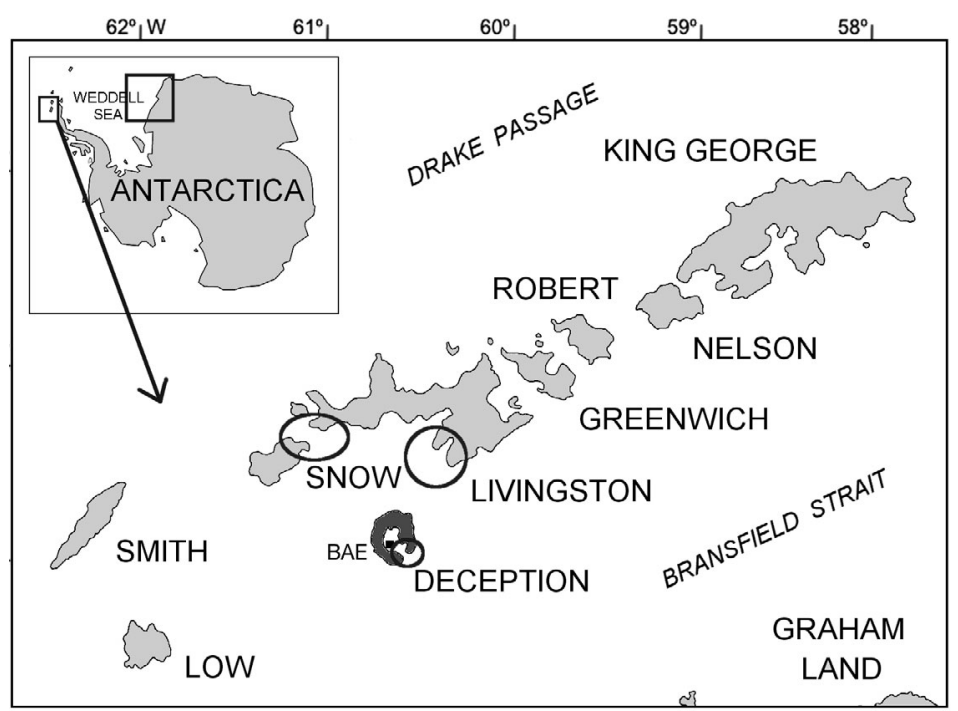

Fig. 1. Main sampling areas (in the 2 squares) for the 4 campaigns on the Antarctic continent, and the South Shetland Archipelago in detail, with sampling points of that particular zone within circles. Dark gray: Deception Island, the location of the Spanish Antarctic Base 'Gabriel de Castilla' (BAE) where the experiments took place done by SCUBA divers using fishing nets to capture aggregations of individuals associated with the pyroclastic sediment and algae, and with traps baited with sardines and deployed for $48 \mathrm{~h}$, which attracted dense swarms of amphipods. Once the experiments were completed, a few specimens were fixed in $70 \%$ ethanol for taxonomy, and the rest were returned to the sea.

\section{Benthos collection and identification}

Marine benthic invertebrate and algal samples of 31 species were collected in the Southern Ocean during 4 Antarctic campaigns: two of them in the eastern Weddell Sea on board the R/V 'Polarstern' during the ANT XV/3 (January to March 1998) and ANT XXI/2 cruises (November 2003 to January 2004); a third on board the R/V 'BIO Hespérides' during the ECOQUIM-2 cruise (January 2006) around the South Shetland Islands; and the fourth during the ACTIQUIM-1 cruise at Deception Island (December 2008 to January 2009; Fig. 1). Sampling was done at a total of 24 stations between $0 \mathrm{~m}$ and $1524 \mathrm{~m}$ depth by using bottom and Agassiz trawls, an epibenthic sledge, and also by SCUBA diving (Table 1). Organisms were sorted on deck, photographed, and a voucher portion or specimen of each sample was fixed in $10 \%$ formalin or $70 \%$ ethanol for taxonomical identification at the Faculties of Biology and Pharmacy (University of Barcelona). All individuals or colonies of each species from a collection site were grouped as a single sample in order to represent mean values of each particular population, and were conserved at $-20^{\circ} \mathrm{C}$ for further examination.

\section{Chemical extractions}

Invertebrates were dissected for withinbody allocation of defensive chemicals when sufficient amounts of sample were available. The sections were cut based on the predictions of the ODT for Antarctic prey, which likely accumulate defenses in the outer layers. Depending on the organism, samples were sectioned into internal (visceral) and external (tunic) tissues in ascidians, external/ internal or apical/basal parts in sponges, or polyparium and axial regions in octocoral cnidarians. The invertebrate and algal samples (either dissected or not), consisting of 
Table 1. Antarctic benthic invertebrate and algal samples collected in the Southern Ocean. AGT: Agassiz trawl; BT: bottom trawl; ES: epibenthic sledge; SD: scuba diving. BAS: basal; API: apical; EXT: external; INT: internal; POL: polyparium; AX: axis body-parts. B\&W: black \& white; Br: brown; O: orange morphotypes

\begin{tabular}{|c|c|c|c|c|c|}
\hline Species & Location & Latitude (S) & Longitude (W) & Gear & Depth $(\mathrm{m})$ \\
\hline \multicolumn{6}{|l|}{ PORIFERA } \\
\hline \multicolumn{6}{|l|}{ Demospongiae } \\
\hline Isodictya toxophila Burton, 1932 & Weddell Sea & $70^{\circ} 57.00^{\prime}$ & $10^{\circ} 33.02^{\prime}$ & BT & 332.8 \\
\hline \multicolumn{6}{|l|}{ Hexactinellida } \\
\hline Anoxycalyx (Scolymastra) joubini Topsent, 1916 (1) & Weddell Sea & $71^{\circ} 06.30^{\prime}$ & $11^{\circ} 32.04^{\prime}$ & AGT & 175.2 \\
\hline Anoxycalyx (Scolymastra) joubini Topsent, 1916 (2) & Weddell Sea & $70^{\circ} 52.16^{\prime}$ & $10^{\circ} 43.69^{\prime}$ & BT & 290.8 \\
\hline Rossella fibulata Schulze \& Kirkpatrick, 1910 & Weddell Sea & $70^{\circ} 57.00^{\prime}$ & $10^{\circ} 33.02^{\prime}$ & $\mathrm{BT}$ & 332.8 \\
\hline Rossella nuda Topsent, 1901 & Weddell Sea & $71^{\circ} 4^{\prime}$ & $11^{\circ} 32^{\prime}$ & $\mathrm{BT}$ & 308.8 \\
\hline Rossella vanhoffeni (Schulze \& Kirkpatrick, 1910) & Weddell Sea & $72^{\circ} 28^{\prime}$ & $17^{\circ} 51^{\prime}$ & ES & 882 \\
\hline Rossella villosa Burton, 1929 & Weddell Sea & $70^{\circ} 55.92^{\prime}$ & $10^{\circ} 32.37^{\prime}$ & AGT & 288.0 \\
\hline Rossella sp. 1 (Orange) Carter, 1872 & Weddell Sea & $70^{\circ} 55.92^{\prime}$ & $10^{\circ} 32.37^{\prime}$ & AGT & 288.0 \\
\hline \multicolumn{6}{|l|}{ CNIDARIA } \\
\hline \multicolumn{6}{|l|}{ Anthozoa } \\
\hline Alcyonium antarcticum Wright \& Studer, 1889 & Weddell Sea & $70^{\circ} 56^{\prime}$ & $10^{\circ} 31^{\prime}$ & BT & 337.2 \\
\hline Alcyonium haddoni Wright \& Studer, 1889 & Deception Island & $62^{\circ} 59.55^{\prime}$ & $60^{\circ} 33.68^{\prime}$ & $\mathrm{SD}$ & 9 \\
\hline $\begin{array}{l}\text { Alcyonium roseum van Ofwegen, } \\
\text { Häussermann \& Försterra, } 2007\end{array}$ & Weddell Sea & $71^{\circ} 17.1^{\prime}$ & $12^{\circ} 36^{\prime}$ & AGT & 416 \\
\hline Primnoisis antarctica (Studer, 1878) (1) & Weddell Sea & $70^{\circ} 52.75^{\prime}$ & $10^{\circ} 51.24^{\prime}$ & BT & 294.8 \\
\hline Primnoisis antarctica (Studer, 1878) (2) & Weddell Sea & $70^{\circ} 52.75^{\prime}$ & $10^{\circ} 51.24^{\prime}$ & BT & 294.8 \\
\hline Thouarella laxa Versluys, 1906 (1) & Weddell Sea & $71^{\circ} 4^{\prime}$ & $11^{\circ} 32^{\prime}$ & BT & 308.8 \\
\hline Thouarella laxa Versluys, 1906 (2) & Weddell Sea & $70^{\circ} 52.16^{\prime}$ & $10^{\circ} 43.69^{\prime}$ & $\mathrm{BT}$ & 290.8 \\
\hline Thouarella laxa Versluys, 1906 (3) & Weddell Sea & $70^{\circ} 52.75^{\prime}$ & $10^{\circ} 51.24^{\prime}$ & $\mathrm{BT}$ & 294.8 \\
\hline Thouarella laxa Versluys, 1906 (4) & Deception Island & $63^{\circ} 02.29^{\prime}$ & $60^{\circ} 36.36^{\prime}$ & AGT & 100.4 \\
\hline $\begin{array}{l}\text { Thouarella minuta } \\
\quad \text { Zapata-Guardiola \& López-González } 2009\end{array}$ & Weddell Sea & $70^{\circ} 56^{\prime}$ & $10^{\circ} 32^{\prime}$ & BT & 338 \\
\hline Umbelulla antarctica Kukenthal \& Broch, 1911 & Weddell Sea & $70^{\circ} 56^{\prime}$ & $10^{\circ} 32^{\prime}$ & BT & 338 \\
\hline \multicolumn{6}{|l|}{ Hydrozoa } \\
\hline Staurotheca antarctica Hartlaub, 1904 & Weddell Sea & $72^{\circ} 51.43^{\prime}$ & $19^{\circ} 38.62^{\prime}$ & BT & 597.6 \\
\hline Symplectoscyphus glacialis (Haderholm, 1904) & Weddell Sea & $71^{\circ} 06.30^{\prime}$ & $11^{\circ} 32.04^{\prime}$ & AGT & 175.2 \\
\hline \multicolumn{6}{|l|}{ CHORDATA (Ascidiacea) } \\
\hline Aplidium falklandicum Millar, 1960 & Weddell Sea & $70^{\circ} 57.00^{\prime}$ & $10^{\circ} 33.02^{\prime}$ & $\mathrm{BT}$ & 332.8 \\
\hline Aplidium fuegiense Cunningham, 1871 & Weddell Sea & $71^{\circ} 7^{\prime}$ & $11^{\circ} 26^{\prime}$ & AGT & 228.4 \\
\hline Aplidium meridianum (Sluiter, 1906) & Weddell Sea & $70^{\circ} 56.42^{\prime}$ & $10^{\circ} 31.61^{\prime}$ & BT & 284.4 \\
\hline Synoicum adareanum (B\&W) (Herdman, 1902) (1) & Weddell Sea & $70^{\circ} 56^{\prime}$ & $10^{\circ} 32^{\prime}$ & BT & 337.2 \\
\hline Synoicum adareanum (B\&W) (Herdman, 1902) (2) & Weddell Sea & $70^{\circ} 55.92^{\prime}$ & $10^{\circ} 32.37^{\prime}$ & $\mathrm{AGT}$ & 288.0 \\
\hline Synoicum adareanum (Br) (Herdman, 1902) & Weddell Sea & $71^{\circ} 06.44^{\prime}$ & $11^{\circ} 27.76^{\prime}$ & $\mathrm{AGT}$ & 277.2 \\
\hline Synoicum adareanum (O) (Herdman, 1902) (1) & Weddell Sea & $70^{\circ} 55.92^{\prime}$ & $10^{\circ} 32.37^{\prime}$ & AGT & 288.0 \\
\hline Synoicum adareanum (O) (Herdman, 1902) (2) & Weddell Sea & $70^{\circ} 56^{\prime}$ & $10^{\circ} 32^{\prime}$ & BT & 337.2 \\
\hline \multicolumn{6}{|l|}{ BRYOZOA } \\
\hline Isoschizoporella secunda Hayward \& Taylor, 1984 & Weddell Sea & $71^{\circ} 06.44^{\prime}$ & $11^{\circ} 27.76^{\prime}$ & AGT & 277.2 \\
\hline \multicolumn{6}{|l|}{ ECHINODERMATA (Holothuroidea) } \\
\hline Peniagone vignioni Herouard, 1901 & Weddell Sea & $70^{\circ} 47.88^{\prime}$ & $11^{\circ} 24.13^{\prime}$ & AGT & 1524.8 \\
\hline \multicolumn{6}{|l|}{ HEMICHORDATA (Pterobranchia) } \\
\hline Cephalodiscus nigrescens Lankester, 1905 & Weddell Sea & $70^{\circ} 56.42^{\prime}$ & $10^{\circ} 31.61^{\prime}$ & $\mathrm{BT}$ & 284.4 \\
\hline \multicolumn{6}{|l|}{ ALGAE } \\
\hline \multicolumn{6}{|l|}{ Ochrophyta } \\
\hline $\begin{array}{l}\text { Adenocystis utricularis (Bory de Saint-Vincent) } \\
\text { Skottsberg, } 1907\end{array}$ & Snow Island & $62^{\circ} 44.01^{\prime}$ & $61^{\circ} 12.2^{\prime}$ & $\mathrm{SD}$ & 1.5 \\
\hline Ascoseira mirabilis Skottsberg 1907 & Livingston Island & $62^{\circ} 45^{\prime}$ & $60^{\circ} 20^{\prime}$ & SD & 0.7 \\
\hline Desmarestia anceps Montagne, 1842 & Deception Island & $62^{\circ} 59.37^{\prime}$ & $60^{\circ} 33.42^{\prime}$ & $\mathrm{SD}$ & 7.5 \\
\hline $\begin{array}{l}\text { Desmarestia antarctica Moe \& Silva, } 1989 \text { with } \\
\text { Geminocarpus austrogeorgiae Skottsberg, } 1907\end{array}$ & Livingston Island & $62^{\circ} 45^{\prime}$ & $60^{\circ} 20^{\prime}$ & $\mathrm{SD}$ & 0.7 \\
\hline Desmarestia menziesii J.Agardh, 1848 & Deception Island & $62^{\circ} 59.02^{\prime}$ & $60^{\circ} 35.85^{\prime}$ & AGT & 109.7 \\
\hline \multicolumn{6}{|l|}{ Rhodophyta } \\
\hline Georgiella confluens (Reisch) Kylin, 1956 & Livingston Island & $62^{\circ} 45^{\prime}$ & $60^{\circ} 20^{\prime}$ & SD & 0.7 \\
\hline Gigartina skottsbergii Setchell \& Gardner, 1936 & Deception Island & $62^{\circ} 59.37^{\prime}$ & $60^{\circ} 33.42^{\prime}$ & SD & 12 \\
\hline Palmaria decipiens (Reinsch) Ricker, 1987 & Deception Island & $62^{\circ} 58.59^{\prime}$ & $60^{\circ} 40.58^{\prime}$ & $\mathrm{SD}$ & 1.3 \\
\hline
\end{tabular}


several individuals or colonies, were exhaustively extracted with acetone and sequentially partitioned into diethyl ether and butanol fractions. All extraction steps were repeated 3 times, except for the butanol, which was done once at the end. Organic solvents were evaporated using a rotary evaporator. Chemical profiles of the obtained fractions were screened by thin layer chromatography. Only diethyl ether extracts (comprising the most apolar lipophilic metabolites) were used further in the bioassays (Table S1 in the supplement at www.int-res.com /articles/suppl/m462p163_supp.pdf). Butanolic fractions and water residues were not tested here, but were kept for future investigations.

\section{Artificial food preparation}

Artificial food was prepared using 2 different protocols. The first one consisted of traditional agar strips on a base of window screen following the method of Hay et al. (1994), except that we reduced the agar proportion from $20 \mathrm{mg} \mathrm{ml}^{-1}$ to $10 \mathrm{mg} \mathrm{ml}^{-1}$ and increased the quantity of food stimulant from $55.6 \mathrm{mg} \mathrm{ml}^{-1}$ to $80 \mathrm{mg} \mathrm{ml}^{-1}$. The second method was new, using alginate caviar-textured pearls made with the Kit Sferificacion ${ }^{\circledR}$ (www.albertyferranadria.com/ eng/texturas.html). During pilot trials with Cheirimedon femoratus, agar strips had disadvantages compared to alginate pearls: (1) lower consumption rates by $C$. femoratus, resulting in longer experimental times, (2) larger amounts of extract required, and (3) the agar had to be heated to $70^{\circ} \mathrm{C}$, possibly resulting in degradation of some compounds in the extracts. Hence, alginate food pearls were selected for our assays. A concentrated blend of powdered dried aquarium food (Phytoplan ${ }^{\circledR}, 17$ to $19 \mathrm{~kJ} \mathrm{~g}^{-1}$ dry weight) was chosen as feeding stimulant to maximize consumption rates. During pilot testing of several diets, including vegetarian sources (Chlorella, Nori, lyophilized Antarctic seaweeds [Desmarestia anceps, D. menziesii, Gigartina skottsbergii], Spirulinabased feed and phytoplankton) and carnivorous sources (krill, Cyclop-eeze mixed zooplankton, fish feed and anchovy paste), Phytoplan ${ }^{\circledR}$ resulted in the highest consumption rates. For the final artificial food recipe, $10 \mathrm{mg} \mathrm{ml}^{-1}$ of alginate (Algin ${ }^{\circledR}$ of Kit Sferificacion ${ }^{\circledR}$ ) aqueous solution containing $66.7 \mathrm{mg} \mathrm{ml}^{-1}$ of feeding stimulant (Phytoplan ${ }^{\circledR}$ ) and a drop of green or red food coloring (see next paragraph) were added dropwise with a syringe to a $0.09 \mathrm{M}(1 \%) \mathrm{CaCl}_{2}$ (Calcic ${ }^{\circledR}$ of Kit Sferificacion ${ }^{\circledR}$ ) water solution, where it gelatinized (i.e. polymerized) to form spheroid pearls approximately $2.5 \mathrm{~mm}$ in diameter. These contained $3.3 \%$ protein, $1.36 \%$ carbohydrates and $1.3 \%$ of lipids (all w/w; based on nutrition facts from Phytoplan $\left.{ }^{\circledR}\right)$.

Tissue extracts were incorporated in the artificial food via Phytoplan ${ }^{\circledR}$. Extracts were dissolved in solvent carrier (diethyl ether) to totally wet the food stimulant, and the solvent was then evaporated, resulting in a uniform coating of the extract on the powdered food stimulant concentrate prior to being added to the alginate aqueous mix. Extracts were applied to Phytoplan ${ }^{\circledR}$ at natural tissue concentrations, and the factor employed to calculate tissue concentrations of each lipophilic fraction (hereafter referred to as the 'natural concentration') was based on the dry weight. The natural concentration was calculated by dividing the ethereal fraction (EE) by the total dry weight $\left(\mathrm{DW}_{\mathrm{T}}=\mathrm{DW}+\mathrm{EE}+\mathrm{BE}\right.$, where $\mathrm{DW}$ is the dry weight of the solid remains of the extracted sample, and BE is the weight of the butanolic fraction). While volume-based normalization is usually applied when dealing with biting predators to calculate the 'defense per unit bite' (e.g. Pisut \& Pawlik 2002), concentrations based on biomass employing wet or dry weight are used with non-biting and biting predators (e.g. Amsler et al. 2005b, Núñez-Pons et al. 2010). When using food pearls, 'defense per pearl' can be measured. We chose dry weight, because it avoids issues of high variability of weight parameters related to water content in aquatic samples, especially sponges. The relative quantity of each extract at natural concentration was then calculated with respect to the total dry weight of artificial food mix required to produce a whole set of extracttreated pearls for a single experiment $(0.03 \mathrm{~g}$ alginate +0.2 g Phytoplan ${ }^{\circledR}=0.23$ g). This quantity guarantees the formation of 150 pearls (15 replicates $\times 10$ pearls per replicate) as well as extra pearls for pilot trials investigating feeding-unrelated changes to the pearls (see next subsection). Control food pearls were prepared identically but without extract, adding an equal volume of solvent alone. Control pearls and treatment pearls (containing extract) were visually distinguished in paired assays by adding different liquid tasteless food colorings (red and green) to the alginate mix before spherification in $\mathrm{CaCl}_{2}$ solution. Pilot trials confirmed that feeding preferences of Cheirimedon femoratus did not differ between colored and uncolored pearls ( $p=0.47)$, or between red and green colored pearls $(\mathrm{p}=0.47)$. Nevertheless, control and treatment food pearls were randomly swapped to green or red colorations throughout the experiments. 


\section{Feeding-preference bioassays with amphipods}

Live Cheirimedon femoratus were maintained in fresh seawater in 81 aquariums at the BAE and were starved for 3 to 5 d prior to bioassays. Each assay consisted of 15 replicates, which were run in separate $500 \mathrm{ml}$ containers, each filled with seawater, 15 to 20 randomly selected amphipods, and a simultaneous choice of 10 control and 10 extract-treated pearls. Amphipods attached to the pearls and ate individually or in groups of up to 5 specimens per pearl. During pilot trials, we periodically monitored and video-filmed amphipod feeding behavior to determine the time course of the experiments. On average a group of 15 to 20 individuals ingested 10 pearls in about 4 to $5 \mathrm{~h}$. Thus, we terminated assays when at least 5 of the 10 pearls of either food type (control or treatment) had been consumed, or $4 \mathrm{~h}$ after food presentation. Amphipods were not re-used in subsequent trials. The number of consumed and unconsumed pearls of each color (control or treatment) was recorded. In pilot trials, food pearls were resistant to degradation during $72 \mathrm{~h}$ exposure to seawater. Since our feeding assays were short $(4 \mathrm{~h})$, we eliminated the need for control assays without consumers to determine changes unrelated to consumption (Peterson \& Renaud 1989).

For each of the 15 replicate containers, the differences in the quantity of ingested control and treated food were calculated. The changes in the amount of the 2 foods in each container are not independent and possess correlated errors. Each replicate is thus represented by a paired result yielding 2 sets of data (treatment and control). Since assumptions of normality and homogeneity of variances were not met, the 2 sets of data were compared using the non-parametric Exact Wilcoxon test in R. Uneaten pearls from completed assays and extra (unused) pearls that had been conserved in seawater were preserved for extraction and analysis by thin layer chromatography, to check for possible alterations in the extracts. No major changes were observed, and since the compounds dissolved in diethyl ether extracts are hydrophobic, there should be little, if any, loss to the water column.

\section{RESULTS}

A total of 40 samples (from 31 species, including different morphs of the same species) were tested: sponges (8), cnidarians (13), tunicates (8), bryozoans (1), echinoderms (1), hemichordates (1) and algae (8). The majority of our samples came from the Weddell Sea area, while 2 anthozoan samples and the 8 algal samples came from shallow coastal areas of the South Shetland Islands (Table 1). No apparent pattern related the incidence of unpalatable chemicals to location or depth. Cheirimedon femoratus was very voracious towards Phytoplan ${ }^{\circledR}$-alginate control pearls, which were ingested at extraordinarily high rates (10 alginate pearls in $4 \mathrm{~h}$ ). Amphipods ate in groups, in accordance with their gregarious behavior, and their feeding preferences were clearly evident. In fact, most of the extracts that yielded unpalatability were barely consumed when included in food pearls, while the paired controls were mostly completely eaten.

The incidence of unpalatable defenses in Antarctic benthic organisms against the omnivorous lysianassid amphipod Cheirimedon femoratus was very high. Out of a total of 52 lipophilic extracts (from different body regions of the 40 samples), 42 extracts ( $80.8 \%$; representing 33 samples from 26 species) were unpalatable for $C$. femoratus. The remaining 10 extracts, obtained from 7 samples belonging to 5 different species, did not exhibit any repellent activity (Fig. 2). The 4 major taxonomical groups tested yielded high percentages of significant feeding repellence against the amphipod, with the ascidians showing the highest incidence (91.7\% of the ascidian extracts were unpalatable), followed by the sponges $(86.7 \%)$, cnidarians $(85.7 \%)$, and algae $(75 \%)$. Extracts from 1 of the 2 samples of the gorgonian Primnoisis antarctica, the hexactinellid poriferan sample Anoxycalyx (Scolymastra) joubini 1, the alga Desmarestia antarctica (with its epiphyte), the bryozoan, the holothurian and the hemichordate caused no rejection by $C$. femoratus. In fact, food pearls containing extracts from the pterobranch (hemichordate) Cephalodiscus nigrescens ( $p=0.002)$, as well as from the algae Adenocystis utricularis ( $\mathrm{p}=$ 0.002) were preferred over control pearls. For dissected samples, the pennatulacean Umbellula antarctica exhibited deterrents in the axial body regions, but the diethyl ether fraction from the polyparium was readily ingested by $C$. femoratus. Moreover, the apical ethereal fraction from the black and white morphotype of the ascidian Synoicum adareanum 2 was palatable, while the barely consumed basal-external and visceral extracts were not (Fig. 2, Table S1).

\section{DISCUSSION}

Tunicates presented repellents in all the samples tested and had the highest proportion of unpalatable extracts compared with the other taxa, indicating a predominant reliance on organic chemical protec- 

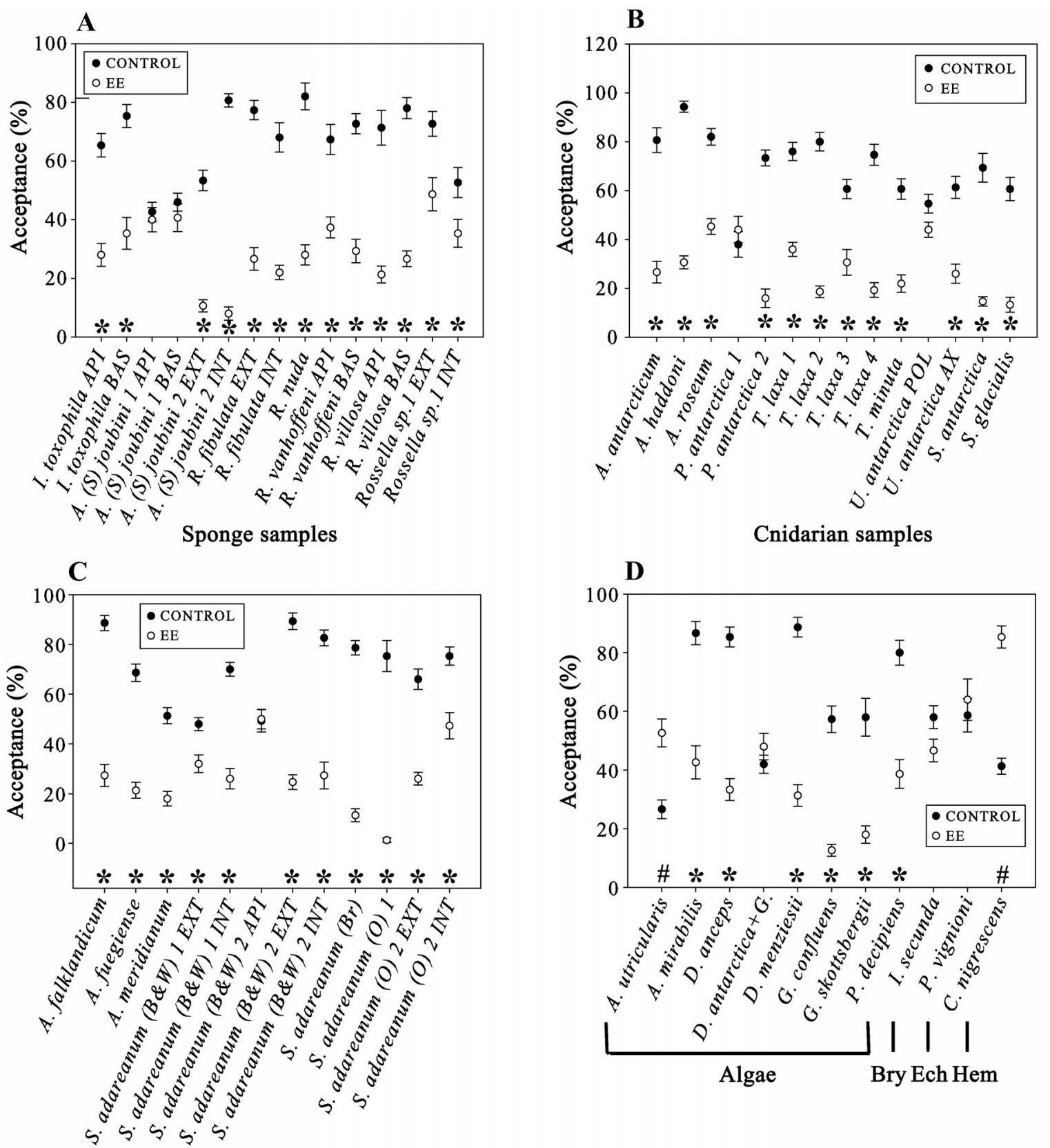

Fig. 2. Cheirimedon femoratus. Results of feeding preference bioassays with the amphipod for the 4 major groups assessed: (A) sponges, (B) cnidarians, (C) ascidians (Synoicum adareanum morphs-B\&W: black \& white; Br: brown; O: orange) and (D) algae and other minor groups (Bry: Bryozoa, Ech: Echinodermata; Hem: Hemichordata). EE: ether fraction of sample extract. Assayed body regions-API/BAS: apical/basal; EXT/INT: external/internal; POL/AX: polyparium/axial body-regions. Data: mean $\pm \mathrm{SE}$ of the percentage of control and extract-treated food accepted. Significant differences (Exact Wilcoxon test, $\mathrm{p}<0.05)-(*)$ : control food preferred; $(\#)$ : treated food preferred

tion. This contrasted with other Antarctic surveys (e.g. Koplovitz et al. 2009). Our samples pertained to common Antarctic colonial species (Varela 2007), some reported to harbor bioactive products (see Avila et al. 2008, Blunt et al. 2011, and previous reviews). In fact, 2 species, Aplidium falklandicum and $A$. meridianum, are known to posses the meridi- anins, defensive alkaloids that cause rejection by the asteroid Odontaster validus, and which are found in inner as well as in outer tissues (Núñez-Pons et al. 2010). Similarly, no allocation of defenses was detected in our tunicate samples. Apparently, repellents are often sequestered in the gonads of tunicates providing protected larval stages (Pisut \& Pawlik 
2002). Other antipredation strategies not measured here describe tunics containing poor nutritional value, or accumulating acid or heavy metals (McClintock et al. 1991, Pisut \& Pawlik 2002, McClintock et al. 2004, Koplovitz et al. 2009, Lebar et al. 2011). Colonial ascidians frequently exhibit intraspecific variability (Varela 2007), and we found 3 morphotypes for Synoicum adareanum: black and white, brown and orange. All were significantly unpalatable except for the apical diethyl ether fraction from a black and white morph of $S$. adareanum. This region concentrated siphon mouths and common cloaca, and is where waste matter from digestion accumulates, which could mask the activity of co-occurring deterrent products (Fig. 2, Table S1). Fresh colonies of $S$. adareanum were previously reported to provoke rejection by the fish Notothenia coriiceps and by $O$. validus, while crude extracts were preferred by the amphipod Gondogeneia antarctica (Koplovitz et al. 2009). Small crustaceans associate with chemically defended substrata including ascidians, obtaining protection from prospective fish predators, as described in Distaplia cylindrica with the amphipod Polycheria antarctica (McClintock et al. 2009). In this sense, the mentioned Antarctic ascidians may also serve as chemical refuges to benthic amphipod species.

Glass sponges are subject to intense predation by Antarctic invertebrates despite their low energetic value (McClintock 1987, Barthel 1995). They are considered to be poor in secondary metabolites (see Blunt et al. 2011 and previous reports), and their extracts have usually displayed little bioactivity (McClintock 1987). However, our results contradict these reports, and all but one of the hexactinellid samples assayed indicated significant unpalatability to our model predator. The palatable extracts from Anoxycalyx (Scolymastra) joubini 1 had lower natural concentrations compared to the unpalatable extracts from a conspecific sample, $A$. (S.) joubini 2, suggesting the presence of lower (and insufficient) quantities of repellents in the former sample (Table S1). Hydrophilic and lipophilic extracts from $A$. (S.) joubini were reported to cause strong tubefoot retractions in the spongivorous Perknaster fuscus (McClintock et al. 2000). This reaction, however, could be due to the highly specialized diet of this sea star, which rarely ingests any prey other than Mycale acerata, and not to the presence of repellents (Dayton et al. 1974). Our sponge samples displayed unpalatable activities in outer and inner tissues, indicating no defense allocation. This differs with the clear distribution found by Furrow et al. (2003), but it is in accordance with what Peters et al. (2009) reported for some of their poriferans. According to the ODT, the expected localization of defensive chemistry primarily to the outermost layers could be highly adaptive against asteroids that feed by extrusion of the cardiac stomach (Rhoades \& Gates 1976). But it might be ineffective towards smaller, biting grazers that can access inner body parts (e.g. of large hexactinellid oscula) through perforations. Amphipods, which occur in high abundance and diversity in association with Antarctic sponges with no obligate host relationships, are clear examples (Kunzmann 1996, Lörz \& De Broyer 2004, De Broyer et al. 2007). However, Amsler and co-workers have ruled out amphipods as a source of significant spongivory and as responsible for the evolution of defenses in Antarctic sponges, after observing that sponge extracts stimulated rather than inhibited feeding. However, the amphipod used in those tests (Gondogeneia antarctica) frequently exhibits increased preferences to foods containing extracts (Amsler et al. 2005b, Koplovitz et al. 2009). Contrarily, in our case, the amphipod Cheirimedon femoratus might certainly play a role in sponges' chemical protection.

Cnidarians are rich sources of bioactive metabolites. In fact, our octocoral samples included species known to possess characteristic natural products (see Avila et al. 2008, Blunt et al. 2011 and previous reviews). Soft corals and gorgonians do not usually have stinging nematocysts, hence chemistry is likely an important defense strategy in these groups (Paul 1992, Sammarco \& Coll 1992). Our results agree with this assumption, and most of the extracts displayed unpalatability. The only exception was the extract from specimens of one anthozoan sample of Primnoisis antarctica, which was consumed by Cheirimedon femoratus; however, the highly concentrated extract from a conspecific sample was rejected (Fig. 2, Table S1). This difference in unpalatability is probably due to natural variability in compound concentrations.

Umbellula antarctica is a flower-shaped pennatulacean devoid of sclerites, consisting of a fine stalk connected to a distant prominent polyparium (Pasternak 1962). During dissection, the sample was separated into the more exposed and nutritious polyparium crowns with few (15 to 30) voluminous polyps, and the axis. The polyparium yielded a rich and palatable extract, reflecting a lack of lipophilic deterrents in this region. Thus, defensive agents are either present in more polar fractions, or the prominent autozooids (3 to $4 \mathrm{~cm}$ long) are protected by their effectively penetrating nematocysts. In oligotrophic regions, 
pennatulid species tend to have fewer but larger autozooids, which practice active macrophagy or carnivory by using their nematocyst system (Dolan 2008). By contrast, the axial stalk of the $U$. antarctica sample (nematocyst-free) did significantly repel Cheirimedon femoratus. Also, different chemical profiles were found in the extracts from polyparium and axis in the thin layer chromatography plates. This could partly be due to the unpalatable metabolites present in the axis but absent in the polyparium. In this case, chemical and nematocyst-based defenses would not be redundant since they protect different body regions. By contrast, both of these strategies co-exist in hydroids (i.e. lipophilic defenses are as common as defensive nematocysts), which is contrary to the OT (Herms \& Mattson 1992, Stachowicz \& Lindquist 2000, Lindquist 2002). Both hydrozoan extracts tested here revealed unpalatability. In the case of Symplectoscyphus glacialis (Sertulariidae), organic repellents are likely required as defense strategy, since the presence of nematocysts is rare. However, species of the Syntheciidae family, like Staurotheca antarctica, possess stinging cells (Shostak 1995); thus, the co-existence of both defenses in this species could be considered as redundant.

The ether extracts of the bryozoan and the holothurian tested did not repel Cheirimedon femoratus in our experiments. It has been observed that certain large-sized acanthonotozomatid and stilipedid Antarctic amphipods commonly include prey from these taxa in their diet (Coleman 1989a, 1990). However, the species analyzed here seem to possess different defensive mechanisms to avoid consumption. The sea cucumber Peniagone vignioni, due to its ability to move and swim, may be less vulnerable to amphipod predation, and might not require chemical defenses (Galley et al. 2008). Similarly, the bryozoan Isoschizoporella secunda uses alternative defense strategies in the form of a calcified structure (Winston \& Bernheimer 1986) and avicularia that can act as traps for small crustaceans (Carter et al. 2010), making unpalatability redundant. The extract from Cephalodiscus nigrescens was inactive, even phagostimulatory (Fig. 2). This pterobranch lives sheltered within a secreted reinforced encasement (Ridewood 1907), which likely already provides enough physical protection against predator attacks. The reliance on more polar defensive metabolites, however, cannot be ruled out in any of these organisms.

Some results of our assays with macroalgal samples agree with previous studies. For instance, the lipophilic extract from Desmarestia menziesii elicited unpalatability as was recorded for other Antarctic graz- ers (Amsler et al. 2005b). The diethyl ether extract of $D$. antarctica with its epiphyte Geminocarpus austrogeorgiae was not repellent in our assay, supporting the assumption that this alga combines acid sequestration with poor organic defenses (Amsler et al. 2005b); however, deterrents might occur in other fractions not tested here. Adenocystis utricularis yielded a palatable extract that was preferred by Cheirimedon femoratus compared to our controls, similar to results from feeding assays with the amphipod Gondogeneia antarctica, but rejection of this alga by sea stars has also been described (Amsler et al. 2005b). However, some of our results disagree with previous findings. For instance, extracts from Palmaria decipiens and Gigartina skottsbergii were rejected by C. femoratus in our assay, but extracts and fresh thalli from these algae have been described as palatable to other amphipods (Amsler et al. 2005b, Huang et al. 2006, Aumack et al. 2010, Bucolo et al. 2011).

In shallow Antarctic marine communities, it has been observed that macroalgal species that host dense amphipod populations in the field are usually rich in feeding deterrents, and are less preferred as prey in laboratory assays. Thus chemically defended algae often harbor high amphipod densities and likely represent refuges (Amsler et al. 2005a,b, Huang et al. 2006, 2007, Zamzow et al. 2010). In contrast to coastal zones, where direct investigations of amphipod habitats may be done by SCUBA diving (e.g. Bregazzi 1972a), determination of temporary host associations on the deeper shelf relies on indirect approaches such as behavioral observations in aquaria of living specimens collected on deep bottoms, or establishment of temporary associations of amphipod species that appear along with potential biosubstrata in sampling trawls (De Broyer et al. 2001). Similarly, our deep invertebrate samples lack information based on direct field observations related to amphipod transitory host associations, since they were collected by trawling.

In benthic ecosystems, biosubstrata represent sources of nutrition for small associated organisms, either because these feed directly on the host, or through casual (indirect) ingestion of host's tissues while foraging on attached detritus and fouling microbiota, such as diatoms. Host organisms also offer structural and/or chemical shelter from predation (Kunzmann 1996, Amsler et al. 2000, De Broyer et al. 2001, Graeve et al. 2001, Amsler et al. 2009, Zamzow et al. 2010). Indeed, amphipods associate with defended invertebrates just as they commonly do with defended algae, because these animals similarly provide chemical refuges from potential preda- 
tors (Richardson 1975, Huang et al. 2007, McClintock et al. 2009, Zamzow et al. 2010). Most of the invertebrate samples tested here from the Weddell Sea and South Shetland Islands contain chemical repellents and could replace macroalgae as hosts in deeper aphotic areas with low or absent algal cover. Generalist amphipods, in particular, usually live associated with chemically defended biosubstrata (Poore et al. 2008). This is likely because their generalist diets allow them to feed on several species other than just the host, thus reducing the consumption of high concentrations of host repellents that may be unpalatable or even toxic (Sotka et al. 2009, Paul et al. 2011). Hence, even if defended potential host organisms may be ingested fortuitously while exploiting other resources in situ (Graeve et al. 2001), low preference for these tissues can be notable in choice-feeding preference experiments in the laboratory. Some of our results with the opportunistic Cheirimedon femoratus could be related to this phenomenon.

When conspecific samples displayed different palatabilities in our assays, the active one was that with the higher extract yields (like in Anoxycalyx (Scolymastra) joubini and Primnoisis antarctica), suggesting possible higher quantities of repellents. This may be due to different chemical composition of samples collected in stations located in geographical areas far apart from each other (Table 1), subjected to diverse environmental conditions and/or genetic variability (Cutignano et al. 2011). Furthermore, variability in palatability could be related to chemical defense induction (Cronin \& Hay 1996, Lindquist 2002, Paul et al. 2011), even though in Antarctica events of inductive defenses have not yet been reported (McClintock et al. 2010).

Effectiveness of deterrents reflects biochemical interactions between a defensive metabolite and a particular consumer. We examined diethyl ether extracts because most of the reported repellents from marine organisms are lipid-soluble, and because amphipods seem more affected by defensive lipophilic metabolites (Koplovitz et al. 2009, Sotka et al. 2009, Aumack et al. 2010). Nevertheless, less lipophilic fractions were kept for future studies. Scavenging lysianassid amphipods have well-developed gustatory gnathopods to typify items chemically and physically while eating (Kaufmann 1994). As a result, necrophagous Antarctic amphipods, including Cheirimedon femoratus, are highly sensitive to food cues (Smale et al. 2007), which may explain the exceptional ability of this species to detect repelling chemicals.

The new experimental protocol proposed here evaluated the incidence of chemical defenses against a significant Antarctic opportunistic consumer, the amphipod Cheirimedon femoratus. The test provided many methodological benefits: (1) requirement of small quantities of extract; (2) short experimental duration $(4 \mathrm{~h}) ;(3)$ ability to assess both algal and invertebrate samples (since an omnivorous predator was used); (4) ease of interpreting results; (5) simple statistical analysis; (6) lack of heating during artificial food preparation, thus avoiding chemical damage; (7) high discriminatory ability of C. femoratus for unpalatable metabolites; and (8) suitability to assess chemical defense in organisms from many Antarctic locations (since a ubiquitous predator was used). Amphipods often provide excellent models for studying feeding behavior since they can be easily manipulated and maintained on artificial diets.

The high proportion of extracts that proved to be unpalatable towards Cheirimedon femoratus, with samples coming from a broad depth range of the Weddell Sea and South Shetland Archipelago, may reflect the importance of this amphipod as generalist consumer affecting the evolution of defenses in Antarctic communities. Moreover, this amphipod species has demonstrated to be a very suitable model predator to perform feeding experiments in future research that will enhance our understanding of the ecological interactions in the benthos inhabiting the shelf of the Southern Ocean.

Acknowledgements. We thank J. Vázquez, B. Figuerola, F. J. Cristobo and S. Taboada for their precious support in the Antarctic cruises. Thanks are due to W. Arntz and the crew of R/V 'Polarstern' for their help on board. UTM (CSIC), 'BIO-Hespérides', 'BIO-Las Palmas' and BAE 'Gabriel de Castilla' crews provided logistic support. We are thankful to M. Mota for statistical advice and to P. Ríos, M. Varela and A. Bosch for taxonomical contributions. Funding was provided by the Ministry of Science and Innovation of Spain (CGL2004-03356/ANT, CGL2007-65453/ANT and CGL2010-17415/ANT). Thanks also to F. Adrià for inventing his Kit Sferificacion ${ }^{\circledR}$.

\section{LITERATURE CITED}

Amsler CD, Moeller CB, McClintock JB, Iken KB, Baker BJ (2000) Chemical defenses against diatom fouling in Antarctic marine sponges. Biofouling 16:29-45

Amsler CD, Fairhead VA, Huang YM, Okogbue IN, Amsler MO, McClintock JB, Baker BJ (2005a) Chemical ecology of ecologically dominant Desmarestia spp. along the western Antarctic Peninsula. 8th Int Phycol Congr, Durban, South Africa, 13-19 August 2005. Phycologia 44(s1): 2 (Abstract)

> Amsler CD, Iken K, McClintock JB, Amsler MO and others (2005b) Comprehensive evaluation of the palatability and chemical defenses of subtidal macroalgae from the Antarctic Peninsula. Mar Ecol Prog Ser 294:141-159 
Amsler MO, McClintock JB, Amsler CD, Angus RA, Baker BJ (2009) An evaluation of sponge-associated amphipods from the Antarctic Peninsula. Antarct Sci 21:579-589

Aumack CF, Amsler CD, McClintock JB, Baker BJ (2010) Chemically mediated resistance to mesoherbivory in finely branched macroalgae along the western Antarctic Peninsula. Eur J Phycol 45:19-26

Avila C, Taboada S, Núñez-Pons L (2008) Marine Antarctic chemical ecology: What is next? Mar Ecol 29:1-70

$>$ Barthel D (1995) Tissue composition of sponges from the Weddell Sea, Antarctica - not much meat on the bones. Mar Ecol Prog Ser 123:149-153

- Blunt JW, Copp BR, Munro MHG, Northcote PT, Prinsep MR (2011) Marine natural products. Nat Prod Rep 28: 196-268

Bregazzi PK (1972a) Habitat selection of Cheirimedon femoratus (Pfeffer) and Thryphosella kergueleni (Miers) (Crustacea: Amphipoda). Br Antarct Surv Bull 31:21-31

Bregazzi PK (1972b) Life cycles and seasonal movements of Cheirimedon femoratus (Pfeffer) and Tryphosella kergueleni (Miers) (Crustacea: Amphipoda). Br Antarct Surv Bull 30:1-34

> Bucolo P, Amsler CD, McClintock JB, Baker BJ (2011) Palatability of the Antarctic rhodophyte Palmaria decipiens (Reinsch) RW Ricker and its endo/epiphyte Elachista antarctica Skottsberg to sympatric amphipods. J Exp Mar Biol Ecol 396:202-206

> Carter MC, Gordon DP, Gardner JPA (2010) Polymorphism and vestigiality: comparative anatomy and morphology of bryozoan avicularia. Zoomorphology 129:195-211

> Coleman CO (1989a) Gnathiphimedia mandibularis K.H. Barnard 1930, an Antarctic amphipod (Acanthonotozomatidae, Crustacea) feeding on Bryozoa. Antarct Sci 1: 343-344

$>$ Coleman CO (1989b) On the nutrition of two Antarctic Acanthonotozomatidae (Crustacea, Amphipoda)-gut contents and functional morphology of mouthparts. Polar Biol 9:287-294

Coleman CO (1990) Bathypanoploea schellenbergi Holman \& Watling, 1983, an Antarctic amphipod (Crustacea) feeding on Holothuroidea. Ophelia 31:197-205

Cronin G, Hay ME (1996) Induction of seaweed chemical defenses by amphipod grazing. Ecology 77:2287-2301

Cutignano A, Zhang W, Avila C, Cimino G, Fontana A (2011) Intrapopulation variability in the terpene metabolism of the Antarctic opisthobranch mollusc Austrodoris kerguelenensis. Eur J Org Chem 2011:5383-5389

> Dayton PK, Robillia GA, Paine RT, Dayton LB (1974) Biological accommodation in benthic community at McMurdo Sound Antarctica. Ecol Monogr 44:105-128

De Broyer C, Jazdzewski K (1996) Biodiversity of the Southern Ocean: towards a new synthesis for the Amphipoda (Crustacea). Boll Mus Civ Stor Nat Verona 20:547-568

De Broyer C, Lowry JK, Jazdzewski K, Robert H (2007) Part 1. Catalogue of the Gammaridean and Corophiidean Amphipoda (Crustacea) of the Southern Ocean with distribution and ecological data. In: De Broyer C (ed) Census of Antarctic marine life: synopsis of the Amphipoda of the Southern Ocean, Vol 1. Bull Inst R Sci Nat Belg Biol, 77(Suppl 1):1-325

> De Broyer C, Scailteur Y, Chapelle G, Rauschert M (2001) Diversity of epibenthic habitats of gammaridean amphipods in the eastern Weddell Sea. Polar Biol 24:744-753

Dearborn JH (1977) Food and feeding characteristics of Antarctic asteroids and ophiuroids. In: Llano GAE (ed)
Adaptations within Antarctic ecosystems. Gulf Publications, Houston, TX, p 293-326

Dolan E (2008) Phylogenetics, systematics and biogeography of dee-sea Pennatulacea (Anthozoa: Octocorallia). Evidence from molecules and morphology. PhD thesis, University of Southamptom

> Furrow FB, Amsler CD, McClintock JB, Baker BJ (2003) Surface sequestration of chemical feeding deterrents in the Antarctic sponge Latrunculia apicalis as an optimal defense against sea star spongivory. Mar Biol 143:443-449

Galley EA, Tyler PA, Smith CR, Clarke A (2008) Reproductive biology of two species of holothurian from the deepsea order Elasipoda, on the Antarctic continental shelf. Deep-Sea Res II 55:2515-2526

> Graeve M, Dauby P, Scailteur Y (2001) Combined lipid, fatty acid and digestive tract content analyses: a penetrating approach to estimate feeding modes of Antarctic amphipods. Polar Biol 24:853-862

Gutt J (2000) Some 'driving forces' structuring communities of the sublittoral Antarctic macrobenthos. Antarct Sci 12: 297-313

Gutt J, Sirenko BI, Arntz WE, Smirnov IS, De Broyer C (2000) Biodiversity of the Weddell Sea: macrozoobenthic species (demersal fish included) sampled during the expedition ANT XIII3 (EASIZ I) with RV 'Polarstern'. Ber Polarforsch 372:1-118

> Hay ME, Kappel QE, Fenical W (1994) Synergisms in plant defenses against herbivores: interactions of chemistry, calcification, and plant-quality. Ecology 75:1714-1726

> Herms DA, Mattson WJ (1992) The dilemma of plants: to grow or defend. Q Rev Biol 67:283-335

> Huang YSM, McClintock JB, Amsler CD, Peters KJ, Baker BJ (2006) Feeding rates of common Antarctic gammarid amphipods on ecologically important sympatric macroalgae. J Exp Mar Biol Ecol 329:55-65

Huang YM, Amsler MO, McClintock JB, Amsler CD, Baker BJ (2007) Patterns of gammaridean amphipod abundance and species composition associated with dominant subtidal macroalgae from the western Antarctic Peninsula. Polar Biol 30:1417-1430

- Kaufmann RS (1994) Structure and function of chemoreceptors in scavenging Lysianassoid amphipods. J Crustac Biol 14:54-71

Koplovitz G, McClintock JB, Amsler CD, Baker BJ (2009) Palatability and chemical anti-predatory defenses in common ascidians from the Antarctic Peninsula. Aquat Biol 7:81-92

- Krapp RH, Berge J, Flores H, Gulliksen B, Werner I (2008) Sympagic occurrence of Eusirid and Lysianassoid amphipods under Antarctic pack ice. Deep-Sea Res II 55: 1015-1023

Kunzmann K (1996) Associated fauna of selected sponges (Hexactinellida and Demospongiae) from the Weddell Sea, Antarctica. Ber Polarforsch 210:1-93

- Lebar MD, Luttenton L, McClintock B, Amsler CD, Baker B (2011) Accumulation of vanadium, manganese, and nickel in Antarctic tunicates. Polar Biol 34:587-590

> Lindquist N (2002) Tridentatols D-H, nematocyst metabolites and precursors of the activated chemical defense in the marine hydroid Tridentata marginata (Kirchenpauer 1864). J Nat Prod 65:681-684

Lörz AN, Coleman CO (2003) Dikwa andresi, a new amphipod crustacean (Dikwidae) from the Scotia Arc. J Mar Biol Assoc UK 83:785-788

Lörz AN, De Broyer C (2004) Description and ecology of a 
spongicolous lysianassoid amphipod (Crustacea) from Antarctica. J Nat Hist 38:889-899

McClintock JB (1987) Investigation of the relationship between invertebrate predation and biochemical composition, energy content, spicule armament and toxicity of benthic sponges at McMurdo Sound, Antarctica. Mar Biol 94:479-487

> McClintock JB, Heine J, Slattery M, Weston J (1991) Biochemical and energetic composition, population biology, and chemical defense of the Antarctic ascidian Cnemidocarpa verrucosa Lesson. J Exp Mar Biol Ecol 147: $163-175$

> McClintock JB, Baker BJ, Amsler CD, Barlow TL (2000) Chemotactic tube-foot responses of the spongivorous sea star Perknaster fuscus to organic extracts of sponges from McMurdo Sound, Antarctica. Antarct Sci 12:41-46

McClintock JB, Amsler MO, Amsler CD, Southworth KJ, Petrie C, Baker BJ (2004) Biochemical composition, energy content and chemical antifeedant and antifoulant defenses of the colonial Antarctic ascidian Distaplia cylindrica. Mar Biol 145:885-894

McClintock JB, Amsler MO, Koplovitz G, Amsler CD, Baker BJ (2009) Observations on an association between the dexaminid amphipod Polycheria antarctica f. acanthopoda and its ascidian host Distaplia cylindrica. J Crustac Biol 29:605-608

McClintock JB, Amsler CD, Baker B (2010) Overview of the chemical ecology of benthic marine invertebrates along the western Antarctic Peninsula. Integr Comp Biol 50: 967-980

Nelson WG (1980) A comparative study of amphipods in seagrasses from Florida to Nova Scotia. Bull Mar Sci 30: 80-89

Núñez-Pons L, Forestieri R, Nieto RM, Varela M and others (2010) Chemical defenses of tunicates of the genus Aplidium from the Weddell Sea (Antarctica). Polar Biol 33:1319-1329

> Nyssen F, Brey T, Dauby P, Graeve M (2005) Trophic position of Antarctic amphipods-enhanced analysis by a 2-dimensional biomarker assay. Mar Ecol Prog Ser 300: 135-145

Obermuller BE, Morley SA, Barnes DKA, Peck LS (2010) Seasonal physiology and ecology of Antarctic marine benthic predators and scavengers. Mar Ecol Prog Ser 415:109-126

Pasternak TA (1962) Pennatulids of the genus Umbellula Cuvier (Coelenterata, Octocorallia) from the Antarctic and Subantarctic waters. Issled Fauny Morei 1:105-128 (in Russian)

Paul VJ (1992) Ecological roles of marine natural products. Comstock Publications Association, Ithaca, NY

Paul VJ, Ritson-Williams R, Sharp K (2011) Marine chemical ecology in benthic environments. Nat Prod Rep 28: 345-387

Editorial responsibility: James McClintock, Birmingham, Alabama, USA
Peters KJ, Amsler CD, McClintock JB, van Soest RWM, Baker BJ (2009) Palatability and chemical defenses of sponges from the western Antarctic Peninsula. Mar Ecol Prog Ser 385:77-85

$>$ Peterson CH, Renaud PE (1989) Analysis of feeding preference experiments. Oecologia 80:82-86

> Pisut DP, Pawlik JR (2002) Anti-predatory chemical defenses of ascidians: secondary metabolites or inorganic acids? J Exp Mar Biol Ecol 270:203-214

> Poore AGB, Hill NA, Sotka EE (2008) Phylogenetic and geographic variation in host breadth and composition by herbivorous amphipods in the family Ampithoidae. Evolution 62:21-38

Rhoades DF, Gates RG (1976) Toward a general theory of plant antiherbivore chemistry. Recent Adv Phytochem 10:168-213

Richardson MG (1975) The dietary composition of some Antarctic fish. Br Antarct Surv Bull 41 \& 42:113-120

Ridewood WG (1907) Pterobranchia. Cephalodiscus. In: National Antarctic Expedition 1901-1904. Natural history, Vol. 2 (Zoology). Trustees British Museum, London, p 1-67

Sammarco PW, Coll JC (1992) Chemical adaptations in the Octocorallia: evolutionary considerations. Mar Ecol Prog Ser 88:93-104

Shostak S (1995) Nematocyst database. www.pitt.edu/ $\sim$ sshostak/cnidocyst_database/ (Accessed 24 Feb 2011)

Smale DA, Barnes DKA, Fraser KPP, Mann PJ, Brown MP (2007) Scavenging in Antarctica: intense variation between sites and seasons in shallow benthic necrophagy. J Exp Mar Biol Ecol 349:405-417

Sotka EE, Forbey J, Horn M, Poore AGB, Raubenheimer D, Whalen KE (2009) The emerging role of pharmacology in understanding consumer-prey interactions in marine and freshwater systems. Integr Comp Biol 49:291-313

- Stachowicz JJ, Lindquist N (2000) Hydroid defenses against predators: the importance of secondary metabolites versus nematocysts. Oecologia 124:280-288

Toth GB, Karlsson M, Pavia H (2007) Mesoherbivores reduce net growth and induce chemical resistance in natural seaweed populations. Oecologia 152:245-255

Varela M (2007) Contribución al conocimiento de las ascidias coloniales (Chordata: Tunicata) de la Antártida Occidental y Región Magallánica. PhD thesis, Universidad de Alicante

Wiencke C, Clayton MN, Gomez I, Iken K and others (2007) Life strategy, ecophysiology and ecology of seaweeds in polar waters. Rev Environ Sci Biotechnol 6:95-126

Winston JE, Bernheimer AW (1986) Hemolytic-activity in an Antarctic bryozoan. J Nat Hist 20:369-374

Zamzow JP, Amsler CD, McClintock JB, Baker BJ (2010) Habitat choice and predator avoidance by Antarctic amphipods: the roles of algal chemistry and morphology. Mar Ecol Prog Ser 400:155-163

Submitted: January 30, 2012; Accepted: May 23, 2012 Proofs received from author(s): August 10, 2012 